\title{
ABO wt Allele
}

National Cancer Institute

\section{Source}

National Cancer Institute. ABO wt Allele. NCI Thesaurus. Code C118323.

Human ABO wild-type allele is located in the vicinity of $9 q 34.2$ and is approximately $2 \mathrm{~kb}$ in leng th. This allele, which encodes histo-blood group ABO system transferase protein, plays a role in blood group determination. Variation of the gene determines whether the protein can catalyze the transfer of carbohydrates to the $\mathrm{H}$ antigen to form carbohydrate antigen A or B on the surface of red blood cells. 